\title{
Pengukuran Ketimpangan Indeks Pembangunan Manusia
}

\author{
Sigit Haryadi; Westi Riani \\ Institut Teknologi Bandung \\ Maret 2018
}

Paper DOI 10.17605/OSF.1O/X9VJT

\section{RINGKASAN}

Makalah ini mengusulkan suatu metoda pengukuran tingkat ketimpangan Indeks Pembangunan Manusia di suatu negara, dengan menggunakan rumus yang dibuat pada bulan April 2016, oleh Sigit Haryadi, dan dinamakan sebagai "Indeks Haryadi”. Metoda ini sangat penting karena dengan mengetahui ketimpangan IPM (Indeks Pembangunan Manusia) di suatu negara, maka pemerintah dapat membuat suatu kebijakan-kebijakan untuk mengatasi ketimpangan tersebut, dimana ketimpangan IPM tanpa disadari adalah merupakan multiplier effect yang bersifat negative, misalnya, terdapat ketimpangan antara kota besar dengan kotakota kecil di sekitarnya, maka akan mendorong orang-orang di kota-kota kecil untuk migrasi ke kota besar, yang akan menjadikan beban bagi kota besar dan menurunkan produktifitas kota-kota kecil.

\section{Kalkulator Internet}

Untuk mempermudah perhitungan, akan dibuatkan suatu "kalkulator internet", yaitu suatu website yang menyediakan kolom isian, dimana kita mengisikan IPM dari semua propinsi di suatu negara atau IPM kota-kota di suatu propinsi, maka kalkulator akan memberikan: (a) Indeks ketimpangan IPM di suatu negara atau di suatu propinsi, (b) Tingkat Ketimpangan IPM di suatu negara atau di suatu propinsi.

Alamat website adalah http://sigitharyadi.net/id/multidicipline/human-development-indexinequality/.

\section{Penjelasan cara perhitungan}

Perhitungan dilakukan dengan cara sebagai berikut:

a) Menghitung share dari IPM dari setiap kota (pada pengukuran ketimpangan IPM suatu propinsi) atau IPM dari setiap propinsi (pada pengukuran ketimpangan IPM suatu negara): $\mathrm{Si}=($ IPM suatu propinsi dibagi dengan jumlah dari IPM semua propinsi) atau = IPM suatu kota dibagi dengan jumlah IPM semua kota di propinsi tersebut.

b) Menghitung ketimpangan Indeks Pembangunan Manusia menggunakan rumus berikut ini: 


$$
\text { Indeks Ketimpangan IPM }=1-\frac{1}{N\left\{\sum_{i>j}^{N} S_{i}^{2}+\sum_{i=1}^{N} \sum_{j=1}^{N}\left(S_{i}-S_{j}\right)^{2}\right\}}
$$

c) Lalu ditentukan tingkat ketimpangan IPM sebagai berikut:

i. Indeks ketimpangan lebih kecil dari 0,005 adalah bersesuaian dengan Tingkat Ketimpangan IPM yang sangat kecil.

ii. Indeks ketimpangan antara 0,005 sampai dengan 0,025 adalah bersesuaian dengan Tingkat Ketimpangan yang kecil.

iii. Indeks ketimpangan antara 0,025 sampai dengan 0,05 adalah bersesuaian dengan Tingkat Ketimpangan yang Menengah.

iv. Indeks ketimpangan antara 0,05 sampai dengan 0,15 adalah bersesuaian dengan Tingkat Ketimpangan yang tinggi.

v. Indeks ketimpangan lebih besar dari 0,15 adalah bersesuaian dengan Tingkat Ketimpangan IPM yang sangat tinggi.

\section{Catatan}

Agar bisa lebih memahami tentang Indeks Haryadi yang menjadi roh pada perhitungan tingkat ketimpangan Indeks Pembangunan Manusia, silahkan membaca buku-buku dan makalahmakalah pada reference, tapi patut dicatat bahwa rumus yang digunakan untuk menghitung tingkat ketimpangan adalah satu dikurangi Indeks Haryadi, karena Indeks Haryadi adalah merupakan indeks kesetaraan.

\section{Reference (Daftar Pustaka)}

[1] Sigit Haryadi. (2017). Haryadi Index and Its Applications in Science of Law, Sociology, Economics, Statistics, and Telecommunications. Penerbit Elex Media Komputindo. Jakarta. ISBN: 978-602-02-9895-5.

[2] Sigit Haryadi. (2017). Indeks Haryadi dan Penerapan di Ilmu Hukum, Sosiologi, Ekonomi, Statistik, dan Telekomunikasi. Penerbit Elex Media Komputindo, Jakarta. ISBN: 978-602-02-9896-2

[3] Sigit Haryadi. (2016). Haryadi Index for Competition, Equality and Correlation Evaluation. Penerbit Lantip Safari Media, Bandung, Indonesia. ISBN: 978-602-732313-2

[4] Sigit Haryadi. (2016). Haryadi Index untuk Evaluasi Kompetisi, Kesetaraan dan Korelasi. Penerbit Lantip Safari Media, Bandung, Indonesia. ISBN: 978-602-73231-31

[5] Sigit Haryadi. (March 17, 2018). The Six 100-year-old Formula Should be Replaced. Researchgate. DOI 10.13140/RG.2.2.21919.66723

[6] Haryadi, S. (2018, March 17). Sepuluh Implementasi Yang Pertama untuk Membuktikan bahwa "The Harmony in Gradation" adalah "The Formula Everything". Retrieved from osf.io/preprints/inarxiv/ja9ve

[7] Haryadi, S. (2018, March 17). The Ten First Implementations to prove that "The Harmony in Gradation" is "The Formula Everything". Retrieved from osf.io/preprints/inarxiv/59szb 
[8] Haryadi, S., \& California, S. H. (2018, March 14). New Method to Calculate the Level of Consistency of the Pauli \& Kraepelin Tests. Retrieved from osf.io/preprints/inarxiv/ty326

[9] Haryadi, S., \& California, S. H. (2018, March 14). Metoda Baru Untuk Menghitung Tingkat Konsistensi pada Tes Pauli \& Kraepelin. Retrieved from osf.io/preprints/inarxiv/qht8j

[10] Haryadi, S. (2018, March 6). Calculation the Equity Level of an Internet Service. Retrieved from osf.io/uzcmq

[11] Haryadi, S. (2018, March 6). Perhitungan Tingkat Pemerataan Layanan Internet. Retrieved from osf.io/preprints/inarxiv/rgct3

[12] Dyah Rakhma Ariyanti; Sigit Haryadi. (October 2017). Analysis of Harmony In Gradation Index on 5G Cellular Network Quantitative Analysis. The 11th International Conference on Telecommunication Systems, Services, and Applications, At Lombok, Indonesia.

[13] Haryadi, S. (2017, November). Probabilitas Statistik Untuk Insinyur. Researchgate. DOI: 10.13140/RG.2.2.14304.58885

[14] Haryadi, S. (2018, February 1). Indeks Haryadi dan Prospeknya Untuk Menjadi Suatu "Formula of Everything (versi 31 Desember 2017). Retrieved from osf.io/zex45

[15] Haryadi, S. (2018, February 1). KALKULATOR untuk membuat Regresi Linier Tanpa Intersep. Retrieved from osf.io/emvs7

[16] Haryadi, S. (2018, February 1). Kalkulator Untuk Mengukur Tingkat Kompetisi di suatu Industri, dengan menggunakan rumus Indeks Haryadi. Retrieved from osf.io/fy7zu

[17] Haryadi, S. (2018, February 17). Calculation the Competition Levels between Students in Class and the Relation to the Teacher or Lecture Fairness in Teaching. Researchgate. DOI: 10.13140/RG.2.2.30359.06569

[18] Haryadi, S. (2018, February 17). Perhitungan Tingkat Kompetisi antar Murid atau Mahasiswa di Kelas dan Kaitannya Dengan Keadilan Guru atau Dosen Dalam Mengajar. Retrieved from osf.io/a894w

[19] Haryadi, S. (2018, February 22). Equality Correlation Calculation. Researchgate. DOI: 10.13140/RG.2.2.22068.76168

[20] Haryadi, S. (2018, February 22). Kalkulator Untuk Menghitung Korelasi Kesetaraan. Retrieved from osf.io/preprints/inarxiv/7r9jy

[21] Haryadi, S. (2018, February 24). Calculation of "Channel Cavity" on Data Communications. Equality Correlation Calculation. Research gate. DOI: 10.13140/RG.2.2.30536.01288

[22] Haryadi, S. (2018, February 24). Perhitungan "Rongga Kanal” pada Komunikasi Data. Retrieved from osf.io/preprints/inarxiv/y3wcg

[23] Haryadi, S. (2018, February 28). Ikhtisar Organisasi Regulasi Telekomunikasi. Retrieved from osf.io/preprints/inarxiv/g9m3k

[24] Haryadi, S. (2018, February 7). Statistik Terapan: Pengujian Regulasi \& Kebijakan Telekomunikasi. Retrieved from osf.io/3pkfw

[25] Haryadi, S. (2018, January 25). Chapter 1. The Concept of Telecommunication Network Performance and Quality of Service. Retrieved from osf.io/mukqb

[26] Haryadi, S. (2018, January 26). Chapter 2 of Network Performance and Quality of Service: Determination of Key Performance Indicator (KPI). Retrieved from osf.io/preprints/inarxiv/6gtnd

[27] Haryadi, S. (2018, January 26). Chapter 3 of Network Performance and Quality of Service: Technical Measurement of a Mobile Network Performance and Quality of Service. Retrieved from osf.io/q4wsz 
[28] Haryadi, S. (2018, January 30). Basic Calculation of the Network's Availability and Reliability (Chapter 4 of Network Performance and Quality of Service). Retrieved from osf.io/preprints/inarxiv/z5mwq

[29] Haryadi, S. (2018, March 1). Kebijakan Lisensi Telekomunikasi. Retrieved from osf.io/7wbjf

[30] Haryadi, S. (2018, March 5). Performance Measurement of Internet Service. Retrieved from osf.io/9nsw3

[31] Haryadi, S., \& Riani, W. (2018, March 5). METODE PENETAPAN TARIF PAJAK PENGHASILAN YANG BERKEADILAN. Retrieved from osf.io/preprints/inarxiv/ayg58

[32] Nie Levin Kusuma Adiatma ; Sigit Haryadi. (2017, October). Comparison of the Haryadi Index with Existing Method in Competition, Equality, Fairness, and Correlation Level Calculation Case Study: Telecommunication Industry. The 11th International Conference on Telecommunication Systems, Services, and Applications, At Lombok, Indonesia.

[33] Sigit Haryadi. (2017). Calculation of the Mobile Communication Competition using Haryadi Index. DOI: 10.13140/RG.2.2.15634.25280

[34] Sigit Haryadi. (2017). Harmony in Gradation and and its prospects as the Formula of Everything (First edition of posts: December 31, 2017). Researchgate. DOI: 10.13140/RG.2.2.19309.08169

[35] Sigit Haryadi. (2017). the Equality Correlation Method. Researchgate. DOI: 10.13140/RG.2.2.10443.80169.

[36] Sigit Haryadi. (2017). The Non-Intercept Linear Regression Method. Researchgate. DOI: $10.13140 /$ RG.2.2.18721.71522

[37] Sigit Haryadi. (2017). The Fairness over Inequality Index: Unfairness is Disaster - a notebook of Sigit Haryadi. Researchgate. DOI: 10.13140/RG.2.2.34379.49449.

[38] Sigit Haryadi. (2017, December). Calculator for Measurement the Competition Index \& Level. Researchgate. DOI: 10.13140/RG.2.2.23626.26568

[39] Sigit Haryadi. (2017, December). Calculator for non intercept linear regression. Researchgate. DOI: 10.13140/RG.2.2.15761.94562.

[40] Sigit Haryadi. (2017, January). Calculation of the Income Equality Levels between Regions using the Haryadi Index. Researchgate. DOI: 10.13140/RG.2.2.36605.77282

[41] Sigit Haryadi. (2018, February). Applied Statistics for Assessment of the Regulation and Policy: case study in Telecommunication Industry. DOI: 10.13140/RG.2.2.15774.02884

[42] Sigit Haryadi; Dyah Rakhma Ariyanti. (October 2017). The Fairness of Resource Allocation and Its Impact on 5G Ultra-Dense Cellular Network Performance. The 11th International Conference on Telecommunication Systems, Services, and Applications, At Lombok, Indonesia.

[43] Westi Riani; Sigit Haryadi. (2017). CALCULATOR for the Government to make the Fair Policy of Tax Rates. Researchgate. DOI: 10.13140/RG.2.2.18550.50246. Available online at http://sigitharyadi.net/multidicipline/income-tax-rates-calculator$\underline{\mathrm{id} /}$

[44] Westi Riani; Sigit Haryadi. (2017). The Method Of Tax Rate Determination Based On Fairness. Prosiding Seminar Nasional SNaPP2017, Bandung, Indonesia.

[45] Haryadi, S., \& Riani, W. (2018, March 12). Telecommunication Competition and Interconnection. Retrieved from osf.io/preprints/inarxiv/7tfqd

[46] Westi Riani; Sigit Haryadi. (2017). Prosiding SNaPP2017 "THE METHOD OF TAX RATE DETERMINATION BASED ON FAIRNESS". Conference: Seminar Nasional Penelitian dan PKM (SNaPP) 2017At: Bandung, Indonesia. 
[47] Sigit Haryadi. (2017). Tantangan Untuk Menerapkan Haryadi Index pada Ilmu Fisika. Jurnal Pendidikan Fisika Sekolah Menengah. Jurnal Pendidikan Fisika Sekolah Menengah. Vol 9 no 1 2017. ISSN: 1979-4959. Available at : https://www.researchgate.net/publication/316683866

[48] Westi Riani; Sigit Haryadi. (2016). Keterbatasan Indeks Gini sebagai Ukuran Ketimpangan Pendapatan dan Solusi Metoda Alternatif. Prosiding SNaPP: Sosial, Ekonomi, dan Humaniora. 